\title{
Problems of financial and investment support modelling of the regional social and economic development
}

\author{
AYGUN GULIYEVA ELDAR \\ Department: Economy of Agrarian Field and Industry \\ Azerbaijan Cooperation University \\ 93 Najaf Narimanov, Baku, AZ1033 \\ AZERBAIJAN
}

\begin{abstract}
The main aim of the research is to investigate the problems of financial and investment support modelling of the regional social and economic development, to analyse the conceptual practical approach to these problems and definition of the adequate mechanisms. Proceeding from the objective situation of the regional social and economic development in Azerbaijan there was justified a complex functional structure of the regions. The factors which enables the sustainable development of the regions, the principles and measures of the financial and investment support were determined. The significance of conceptual practical approach to financial and investment support of the regional social and economic development was revealed. The significance of financial and investment support in the modelling of social economic development on the regional level, the maximum rational use of the local natural and economic supplies in formation of the financial resources, and enterprises modelling issues were analysed. There was prepared a structure of regional investment policy formation and implementation system. The formation factors and implementation ways of preparation mechanisms of the regional investment policy were determined. The directions of strengthening of the finance and credit support of the social and economic development programs were justified. There was also given a scheme of strengthening of the financial and credit support rationality of the regional social economic development program. The fraction of regions in the total amount of the economic agents in Azerbaijan was analysed. There was prepared a scheme of important directions of the multiplicative effect in the social economic development of the regions. The efficiency issues of the regional social economic development program in Azerbaijan were analysed. There were presented the dynamics of funds oriented to the nominal capital on regions in Azerbaijan and dynamics of funds oriented to the nominal capital per capita on regions. The current situation of the regional social economic development in Azerbaijan and production of outputs on the economic regions were analysed. The dynamics of outputs production per capita in the main fields of economics region-wise and the dynamics of industrial production volume region-wise were also presented. There were generalized the factors determining the strengthening of financial and investment support of the regional social economic development. There were shown the ways of strategic approach to the financial and investment support of the social economic development in the regions in the short and long terms in Azerbaijan. There were prepared suggestions and given advice on the issues reviewed in the article. This is a sample of the format of your full paper.
\end{abstract}

Key-Words: - Azerbaijan, Financial and investment support, regional economic potential, regional economic policy, social and economic development, financial and investment support, interregional economic development differences, regional natural resources.

Received: March 15, 2020. Revised: August 1, 2020. Accepted: August 8, 2020. Published: August 14, 2020.

\section{Introduction}

The economics of AZERBAIJAN appeared for the element of the former soviet empire during the long period of 70 years (1920-1990). Back then there were no available capabilities for development of the economic modelling of the country or regional development programs. Everything was solved in the centre - in Moscow. Other ways of saying Moscow determined the programs and economic development tendencies which it considered necessary for AZERBAIJAN. The resources were also divided from the centre. It is worth to mention one interesting detail: for example, in Sumgait industrial centre the two huge chemical enterprises were divided by just a 3 fence but these two plants did not have a right on independent division of resources and raw materials between them. This issue had to be reviewed definitely three thousand kilometres away in Moscow and the work had to be done on the basis of the solution received from there. All financial issues were solved the same way. The government of AZERBAIJAN could not independently divide the financial resources, and 
allocate funds for development programs of the regions. Imagine that the issue of construction of any infrastructure object in a distant village in AZERBAIJAN was solved in Moscow and the financial resources were also allocated from there. Of course, all these became history. After restoration of independence in 1990 AZERBAIJAN had already to conduct a free economic policy, social economic reforms and to solve the issues of preparation of the regional development programs itself. From this point of view the national economic interests, the economic development tendencies of the country and especially the perspectives of regional development modelling grew up. It is interesting that on January 15, 1992 the law about 'Foreign investment protection' was adopted. The law about 'Investment operations was put in force on January 13th, 1995. It means that during a short period of time after resonation of independence the government of AZERBAIJAN was quite interested in bringing foreign investments to AZERBAIJAN and in increasing the attractiveness of these processes and took active measures in this field. It is known that the realization of the economic reforms is impossible without financial resources and the balanced regional social and economic development programs requires the serious level of finance and credit maintenance. Formation of sustainable and continuous financial resources and adequate modelling of the regional development to the national economic interests of the country depends on each other very much. For this reason, making investments to the regions is one of the important fields of activity of government in its economic policy. The objective scientifical and practical approach is the main criteria in this article. Our main goal is to reveal the modern essence of the balanced regional social and economic development in AZERBAIJAN, to show the local problems. For this reason, we did not want to overload the article with the existing economical theoretical views and 4 approaches; in the article alongside with avoiding these thoughts we gave preference mainly to find the solution of the problem by benefit of the social and economic stability already existing in modern AZERBAIJAN and economic development tendencies. The modern scientific and practical standpoints on increase of the finance and credit supply of the regional development programs in AZERBAIJAN are covered in the article. Alongside with all these under the circumstances of global economic challenges of the regional social and economic development and important economic transformations the definition and measurement of tendency direction, the preparation of the sustainable mechanisms of the finance and credit supply in the processes and suggestions for implementation stand in the centre of the reviewed problem. Truth be told, the aim is quite actual and important, but the challenges ahead are much more complicate. First of all, we considered necessary to give our opinion to the researches on these issues, to the arguments mentioned in economics literature, to the scientific approaches and thoughts, and statistic and the other data bases, and explore the study level of the given issues. If make a generalization the issues covered in the article are connected with finance and investment supply modeling of the regional social and economic development in Azerbaijan. First of all, it is considered important to investigate the content of finance and investment supply of the regional economic importance and regional social and economic development. On the assumption of objective assessment of the resource and industry level in the region, human resources, business development level, investment and real analyses, the determination of increase directions of the finance and investment supply in the regions is one of the main problems. The problems of elimination of maladjustments between social and economic development of the regions, the growth of population's income in the regions, the problems of economic activity increase are also remained in the center of attention. The importance and solution of issues of finance and investment supply reinforcement and factors connected with them were reviewed and the relevant mechanisms and suggestions were prepared with the aim of modeling of the social and economic development of the regions.

\section{Problem Solution}

As mentioned above taking into consideration the modern strong economic transformations and complexity of global economic appeal we decided that usage of last year's economic literature and resources was more rational. But in formation of the main thoughts and considerations on the issues the major place is given to author's approaches. Of course, this is not an evidence of a cold approach to the other economic thoughts and statements, each research work has its own scientific essence and practical value. Taking these into consideration there were declared against the problems indicated in the article according to the theoretical views of a group of classic economists and the other world economists: [47], [5], [29], [49], [44], [48]. Under 
the condition of treating classic economic views and many world scientists' thoughts and statements with respect we would like to mention that in the article the preference was given mostly to scientific practical approaches to the reviewed issues adequate to the last years global economic appeals. The regional social and economic development processes taking place in Azerbaijan and the mechanisms of finance and credit supply of these problems require new approaches, mechanisms considering local specific characteristics and economic tools. From this point of view, it is quite difficult to mention the fundamental study of the financing issues of the regional development programs in Azerbaijan. Thus, the existing economic practical mechanisms and the thoughts, suggestions and advice mentioned in the economic literature are not enough to solve the existing problems and their relevance is not adequate. Azerbaijan researches such as [34], [2], [21], [22], [3], [46], [4] conducted researches, prepared monographs, expressed their thoughts and made suggestions about the complex problems of the social and economic development, importance and modeling of the regional development programs, the positive and negative features, the issues of financial and credit supply of these development programs and finance and investment supply. Taking into consideration these problems the works of a group of young Azeri researches such as [1], [9], [28], [32], [39], [40], [45] attract attention last years. The regional economic development processes and the issues of financial and investment supply related to them were in the highlight of a number of world researches. As an example we can show the scientific articles and research works of [7], [11], [12], [14], [15], [16], [18], [20], [27] [37], [43], [51], [52], [53], [54], [55] and etc. Alongside with all these we would like to notify that the modeling problems of financial and investment supply of the regional social and economic development in Azerbaijan are quite relevant and have a strategic impact for our country. For this reason, the importance of problems reviewed in the article is approached by the features and tendency of regional economic development processes taking place in Azerbaijan.

\subsection{Analysis of the conceptual and practical approach to the finance and investment supply of the regional social and economic development.}

The social and economic development priorities of each country are directly linked to the economic development features of the country, the objective reality and optimal modeling of the regional development. After accomplishing the phase of its economic reforms Azerbaijan achieved the boosting of regional social and economic development to the priority activity level. The two state programs on the regional development which followed and complemented each other were realized and the third sate program is now being developed. We are not going to list off the main essence of these state programs. The problems of renovation or improvement of the most social and economic development components in the regions of the country and also of the financial a divestment supply mechanism attracts attention. And what is the region, the modern elements of regions, what the formation or development components consists of? As the main factors in formation and development of any region, the adequateness of the natural resources and population base in this region, formation of market infrastructure, production, social, ecological and institutional infrastructure components are of great importance. Professor Nuriyev A. [34] considers the finance and investment supply of social and economic development in the regions to be the determinative factor Professor Atashov B. [34] mentions that investment funds in Azerbaijan began to appear comparably later than commercial banks. Taking into consideration that some problems have already appeared nowadays in the bank system in Azerbaijan it means that it is not still so real to wait the valuable results from the investment funds activities in the country. From this point of view the financial and investment supply in the regions of our country have to be emulated in a complex and systematic way. Thus, in reality the balanced development of the regions have to be considered in a balanced manner with the provision of national economic security of each country and one of the main tasks in these processes is establishment of the secure financial system. For that end first of all the optimal limit of the government intervention into the private and state financial institute activities and the methods of achieving it should be determined. Besides it the provision of government intervention transparency should be also kept in the center of attention. The determined optimal intervention levels between the state and private sectors can cause the increase in rational use of the resource potential in the region, formation of the sustainable and productive financial resources, and maximum effective use of the capital and labor resources in the region. Besides this, the government must provide the 
attraction of investment in the regions for the maximum effective use of the population labor resources, creation of the effective infrastructure and competitive production enterprises network.

\subsection{The essence of conceptual practical approach to the financial and investment supply of the social and economic development in the regions}

A conceptual approach to the increase of investment attraction and financial resources formation in the region should be provided. The different factors in the regions, the internal and external factors influencing the formation and development of the region should take place adequate to their features in this conceptual approach. It's no coincidence that in spite of the concept of investment is one of the essential categories of the market economy, we can observe the quite serious control of it. The source of this variety is the position of both classic and neoclassic, Keynesianism and Neo-keynesianism economic schools and contradictions of the modern reality. The representatives of classic political economy consider with big foresight that 'any increase or decrease of the capital will naturally cause the increase or decrease of the industrial activities, the number of production workers, and as result the annual value of products on the land and labor of the country, the real wealth and income of its population [47]. We would like to note that the conception of state regulation of the economics composes the theoretical and methodology, and practical base of the investment policy as an essential part of economic policy. J.M. Keynes's point of view on investment which gives proof to the non-compliance of the market in the pure form with social and ecological requirements of the society and the relevance of state regulation of the modern economics, conforms the terminology of the current investment policy the most. Thus, as to the Keynes who notes that investment increase gives an impetus to economic activity, "an investment is a purchase of an old or new property by a person or corporation. In some instances, this conception is limited by purchase and sale of paper holdings on stock-market. At the same time, for example, in the purchase and sale of a car or a house it can be referred to the investments in gathering stock of the finished manufactures or uncompleted production" [29]. The diversity of financial supply in the region, creation of sustained and productive finance resources depends on attracting investment in the region. Or the new economic appeals stipulate the enhancement of the economics, abolition of the trans-regional economic differences [51]. In a number of developing countries such as China, Mexica, Brazil and India, the issues of abolition of the trans-regional economic differences attracts attention [54]. R. Capello considers that the power improvement of the local production in the development of the regions and rational use of the advantages of the regions are the important issues [14]. In accordance with the research based on the 125 country's information K. Harshana arrived at an important conclusion that enterprise development plays an important role in increase of economic potential and economic perspectives of the regions [20]. The complex development of the infrastructure in the regions must be seriously in the highlight [18]. In addition, the intensity and enhancement of the industrialization in the regions can assert great positive influence on the development of the region and financial investment supply [37]. From the other side, the effective use of the resources in the regions and also the enhancement of the clusterization will form the potential of productive influence on the social and economic development of the regions [15] and etc. We deem it advisable to give preference to the approach of proceeding from real objectivity on the level of regional economic development in Azerbaijan and modern economic appeals in the review of such kind of issues. It is obvious that in this approach all the mentioned above are also considered and generalized. We also considered the different approaches and scientific views in our efforts to form the regional investment policy and to build the structure of its implementation system. We consider that for preparation of the regional development investment policy and its implementation first of all the regional investment policy has to be developed and the factors forming the realization mechanisms have to be determined ad listed in accordance with their importance level, after that the formation levels of the regional investment policy have to be specified, and at last the ways to achieve the goals of regional investment policy have to be chosen (see: Figure 1) 


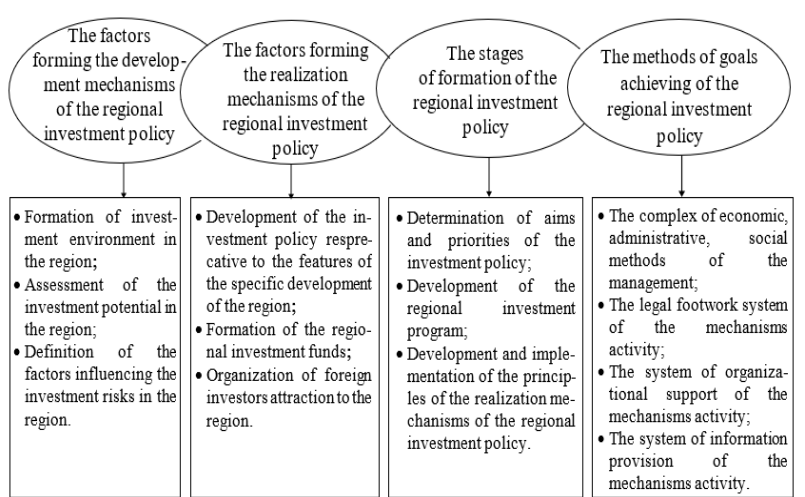

Figure 1. The structure of formation and implementation of the regional investment policy (composed by the author).

As we can see from Figure 1 the factors forming the development mechanisms of the regional investment policy and the mechanisms of realization of this policy, the levels of regional investment policy formation and the ways to achieve the goals of the regional investment policy stipulates the complex and systemic approach to many problems. Implementation of the resultsoriented directions of the social and economic developments in the regions and modeling of the finance and credit supply in these processes are of important conditions. Increase of competitiveness of the regional economics is especially kept in the center of attention. At the other end of the scale from the point of view of investment attracting and its rational use, more attention should be given to formation of the definite infrastructure and development issues. The finance and credit system plays a huge role in financing of the real sector of the economics [12]. To create a multiplicative effect of the social and economic development in the regions, the investment activity should possess the necessary development rate and coverage area in the real sector. Let's review some points simulating the necessity to review the processes of multiplicative effect creation of the social and economic development in the country regions and strengthening of the national economic security in the unified complex. First of all, we should mention that the multiplicative effect is related to investment processes, and these processes are related to the features of investment flows. A multiplicator reflects the interrelation between the national income and investment amounts. As to interrelation which causes the increase between the national income and investment [12]. By differentiating the factors creating the multiplicative effect from the point of view of the character influencing the investment volume and structure, on the different levels and stages of the economic development the estimation of their place and role demands the complex research. In addition to all mentioned about the multiplicator we would like to note that the fiscal policy instruments, and also taxes and customs duties should be especially mentioned alongside with the factors stipulating the economic growth and influencing the investment value and structure. Generation of a prompt system of the regional economic regulation by means of these tools possess the real opportunities for strengthening the multiplicative effect created by the social an economic development in the regions as it can be seen from the progressive experience. Usually, with consumers increasing tendency for acquisition, in other words as long as they decrease the intake, the multiplicator also decreases. And conversely, if consumers increase the funds allocated to the intake from the increased income (of course, in this situation the funds directed to the acquisition decrease) the multiplicator also increases. It is hard to agree with the opinion that a country with mixed economy can achieve the change of its real national product structure in the direction of capital increase and current consumption decrease in the terms of high employment by provision of the necessary integrity of the fiscal and credit funds policy's [44]. The important directions of the multiplicative effect in the social and economic development of the regions were indicated in Figure 2. 




Figure 2. Approximate scheme of important directions of the multiplicative effect in the social and economic development of the regions (prepared by the author).

While reviewing the Figure 2 we will see that the financial investment supply can be evaluated as an important term in realization of each important direction of the multiplicative effect in the regional social and economic development. Thus, organization of the rational use of the resource potential in the region, strengthening of population's economic activity, support of enterprise development, solution to the employment problem, implementation of high technologies, realization of innovative functions, enhancement of "state-private sector" cooperation and finally solution of social and economic problems are directly associated with availability of sustainable and adequate finance and investment supply mechanisms primarily and their further realization.

\subsection{The effectivity problems of financial and investment supply of the regional social and economic development in Azerbaijan}

As we have mentioned before with the aim of acceleration of social and economic development of the regions in Azerbaijan the state programs of wide format are used actively and consistently. For example, in 2004-2008, 2008-2014 the 1st and the 2nd state programs were realized consistently, and now the state program on 2019-2023 years is in process of realization. In 2004-2008 the increase in state investment volume gives a fillip to increase of infrastructure, communal, social service objects building several times and increase in quality of the service sector [9]. The stability of the average annual inflation rate and the exchange rate of the national currency at an acceptable level were achieved, optimal tax and customs rates were established, grain production increased, export activities of producers were stimulated, budget revenues in the non-oil sector were increased. The most of these measures are directly connected with commissioning of important infrastructure objects. In the framework of the second large state program of the regional economic development in Azerbaijan (2009-2013) the main priority activity directions consisted of modernization of the rural sector in the regions and strengthening of the market infrastructure. The third large state regional development program (2014-2018) is connected with diversification of economics in the regions, development of import replacing areas, increase of production of the export directed and competitive outputs, development of enterprise, and improvement of the business environment. The financial resources for main capital on Azerbaijan regions during 2005-2018, the funds per capita and the share of regions in the total funds are indicated in Table 1 and Figure 3.

Table 1. The funds directed to the main capital on the regions (mln USD) and per capita (USD) in Azerbaijan

\begin{tabular}{|c|c|c|c|c|c|c|c|c|}
\hline & 2005 & $\begin{array}{c}\begin{array}{c}\text { Per } \\
\text { capita }\end{array} \\
\end{array}$ & 2010 & $\begin{array}{c}\text { Per } \\
\text { capita }\end{array}$ & 2015 & $\begin{array}{c}\text { Per } \\
\text { capita }\end{array}$ & 2018 & $\begin{array}{c}\text { Per } \\
\text { capita }\end{array}$ \\
\hline Countrywide & 6099,8 & 713,18 & 12342,0 & 1443 & 15551,1 & 1602,3 & 10144,04 & 1016,3 \\
\hline Baku & 5390,3 & 2774,93 & 8449,3 & 3680,81 & 11165,87 & 5016,55 & 6308,1 & 2769,7 \\
\hline Absheron & 143,25 & 309,1 & 148,3 & 283,6 & 381,1 & 683,2 & 719,9 & 1257,4 \\
\hline Ganja-Gazakh & 73,47 & 64,60 & 523,92 & 44,0 & 637,75 & 508,86 & 450,25 & 350,6 \\
\hline Shaki-Zagatala & 16,92 & 30,66 & 228,6 & 397,4 & 209,34 & 345,4 & 225,9 & 363,6 \\
\hline Lankaran & 98,0 & 124,0 & 167,7 & 197,7 & 332,1 & 366,7 & 293,1 & 312,7 \\
\hline Guba-Khachmaz & 36,2 & 76,6 & 692,9 & 1390,2 & 262,9 & 492,3 & 267,8 & 487,4 \\
\hline Aran & 123,96 & 72,13 & 694,5 & 400,9 & 1078,4 & 549,8 & 866,1 & 427,5 \\
\hline Upper Garabakh & 45,0 & 75,4 & 105,9 & 169,7 & 40,8 & 617,3 & 39,8 & 58,3 \\
\hline Kalbajar -Lachin & 0,73 & 3,4 & 0,96 & 4,4 & 0,19 & 0,87 & 0,3 & 1,02 \\
\hline $\begin{array}{l}\text { Mountainous } \\
\text { Shirvan }\end{array}$ & 28,0 & 103,6 & 228,3 & 793,1 & 148,1 & 480,7 & 186 & 583,8 \\
\hline Nakhchivan & 133,3 & 348,9 & 624,3 & 1522,4 & 927,0 & 2086,0 & 598,2 & 1311,7 \\
\hline
\end{tabular}

Note: The table was prepared by the author on the basis of the official information of The State 
Statistical Committee of the Republic of Azerbaijan: http://azstat.org.

The regions share in the resources directed to the main capital in Azerbaijan in 2015 and 2018 were indicated (as \%) in the Figure 3. In 2015 as compared to 2005 the share of Aran region increased from $2 \%$ to $7 \%$. The share of Baku decreased from $88.4 \%$ to $72 \%$ at that period and to $62 \%$ in 2018 . The increase in Nakhchivan region composed from $2.25 \%$ to $6 \%$, and in GanjaGazakh economic region composed from $1.20 \%$ to $4 \%$.


Figure 3. The share of regions (in \%) in the funds directed to the main capital in Azerbaijan during 2015 and 2018 (Prepared by the author on the basis of statistical information).

3.4. The analysis of the current state of the regional social and economic development in Azerbaijan. The remarkable thing is that during 2005-2018 in Azerbaijan the dynamism in the regional social and economic development was provided. The output of products on the economic regions of the country is indicated in Figure 4.

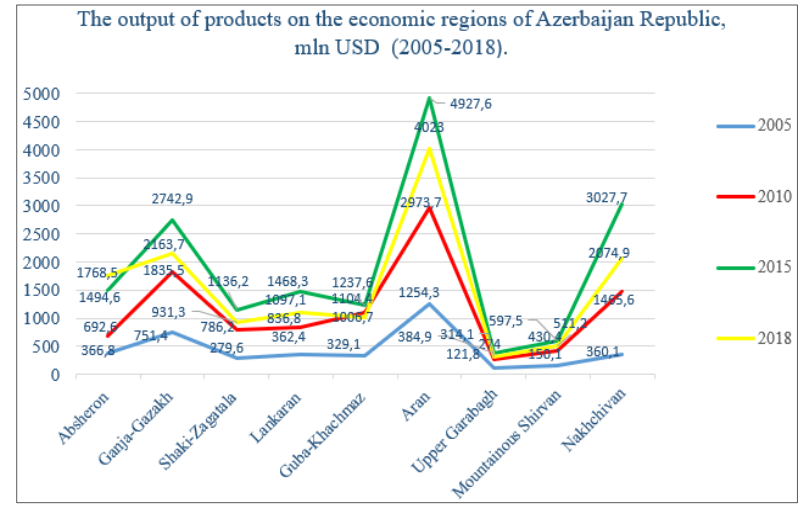

Figure 4. The output of products on the economic regions of Azerbaijan Republic, mln USD (2005-2018).

On the basis of Figure 4 we can mention that during 2005-2015 production of outputs in Aran economic region increased 3.93 times and amounted to $4927,6 \mathrm{mln}$ USD in 2015. During that period the increase in in Absheron economic region - 4.1 times, Ganja-Gazakh economic region - 3.65, Shaki-Zagatala economic region - 4.1, Lankaran economic region - 4.1, Guba-Khachmaz economic region - 3.76, Upper Garabagh economic region - 3.16, Mountainous Shirvan economic region -3.98 and Nakhchivan economic region - 8.41 times. In 2018 these indicators decreased. As it can be seen in 2018, product output by economic regions relatively decreased (for example, 4.1 times in 3 regions). In Figure 5 there are indicated the shares of economic regions in the production of outputs in 2018.

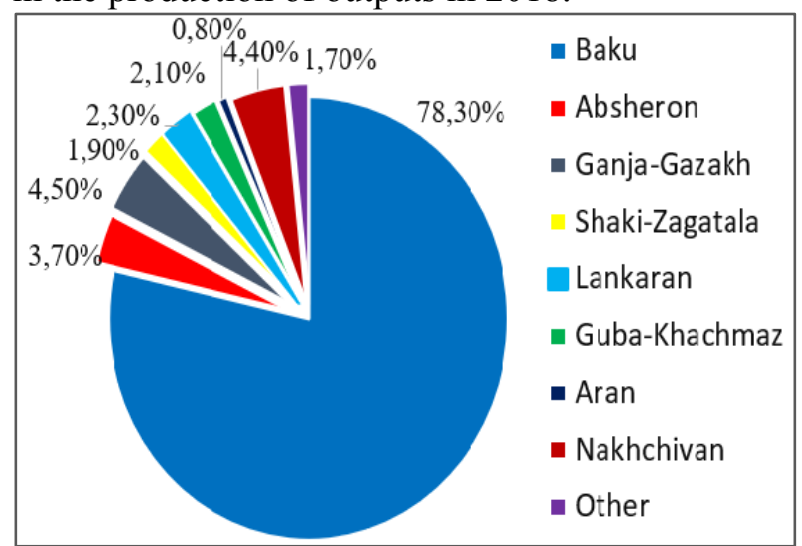

Figure 5. The share of economic regions in the output of products in Azerbaijan in 2018 (as \%; total 100\%).

The output of products per capita in the main fields of economics on the regions in Azerbaijan from 2005 to 2018 is indicated in Figure 6. 


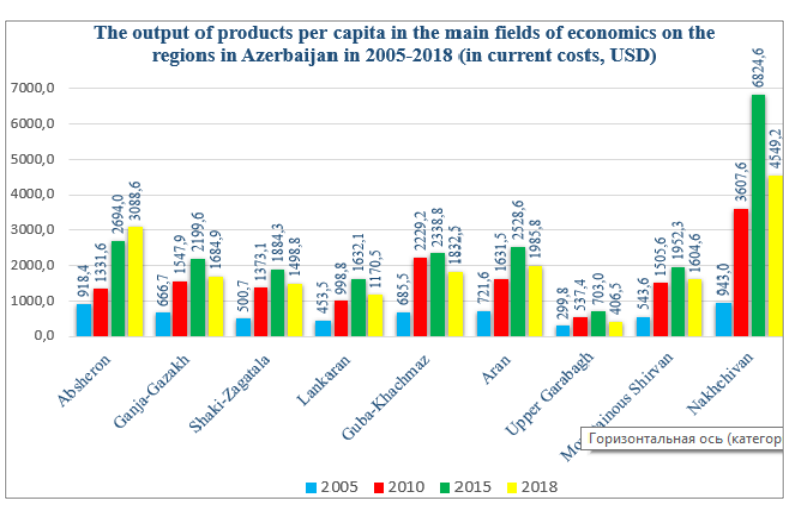

Figure 6. The output of products per capita in the main fields of economics on the regions in Azerbaijan in 2005-2018 (in current costs, USD)

The incomes per capita on economic regions of Azerbaijan Republic (2005-2018) are indicated in Figure 7.

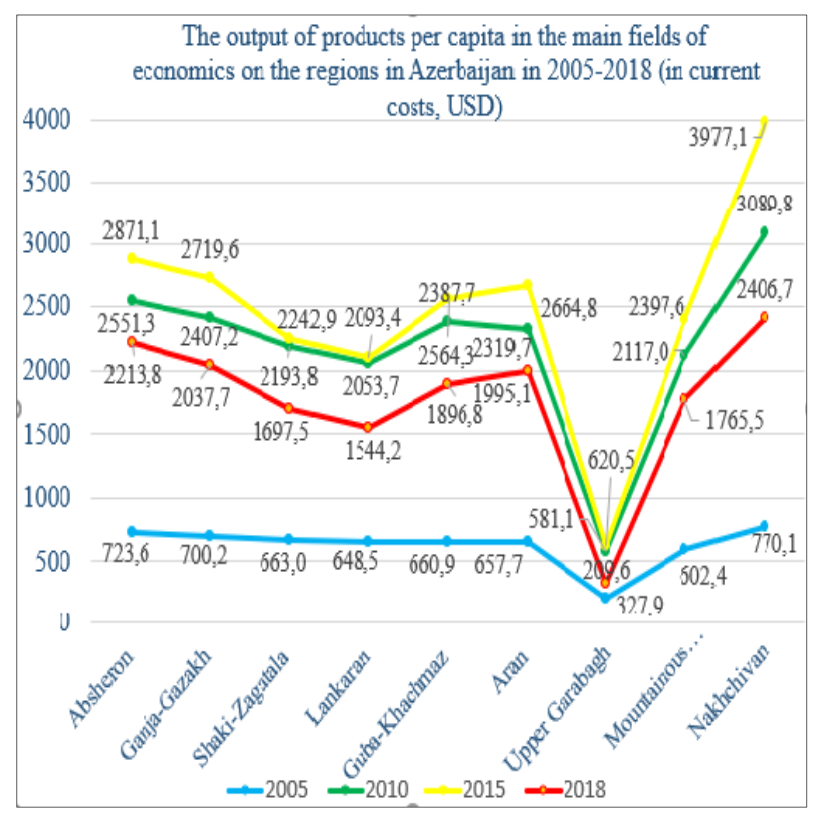

Figure 7. The incomes per capita on economic regions of Azerbaijan Republic, USD (20052018).

The regional distribution of new work places opened in Azerbaijan Republic in 2015 is indicated in Figure 8.

The regional distribution of new work places opened in Azerbaijan Republic in 2015, (as \%) (115869 work places in total)

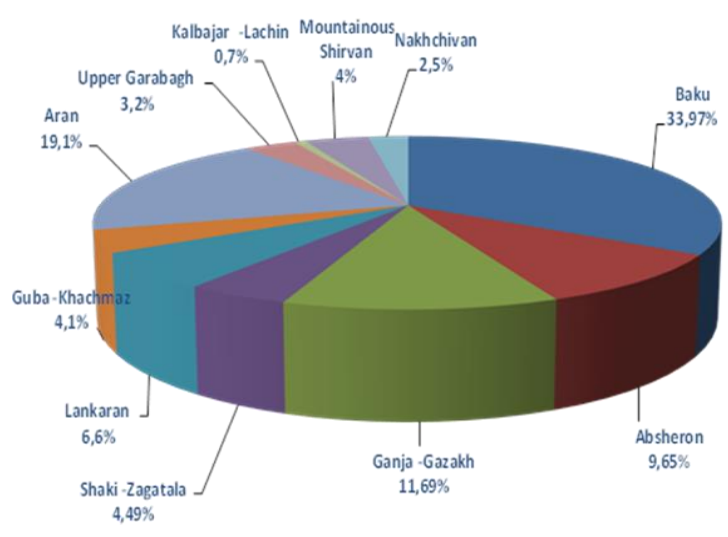

Figure 8. The regional distribution of new work places opened in Azerbaijan Republic in 2015, as \% (115869 work places in total).

It is worth to note that the objective review and evaluation of the factors stipulating the strengthening of financial and investment supply of the regional social and economic development in Azerbaijan in present time is of great importance. Thus, the strengthening of finance and investment supply in the regional economic development modeling in Azerbaijan requires the complex review of a group of issues and substantiation of the factors caused by this. Alongside with macroeconomic problems of the finance and investment supply improvement the development and realization of the optimal variant of the financial and investment policy in the regions, especially the models taking into consideration the specific development tendencies in the regions is very important [32]. Defining the priorities of regional economic development the real situation on the available between the regions financial and investment, natural resources, material and technical, infrastructure and staff potential should be objectively evaluated, and the social economic development programs adequate to the different advantages of each region should be prepared, the financial and investment supply of these programs should be measured and planned [17]. The orientation of mutual relations between a region and the center on the productive activity direction and the active participation of the center in the objective determination of the financial investment supply in increase of the regional repeated production volume are the important terms in modeling of regional economic development processes. In all cases turning on the 'green light' to the intensive flow of financial investment resources from the center to the regions is considered to be very important. The swear by the regional economic development of the central 
government, keeping the regional problems in the center of attention created the conducive conditions for strengthening of the necessary financial and investment supply alongside with making positive impact on realization of the regional economic development programs. In present time one of the most important problems of the regional economic development consists of reaching the sustainable growth in both economic and social field in this direction. With this aim to achieve the economic rationality in the regions the rational use and arrangement of the resource and production potential, creation of the network of competitive enterprises in the regions, abolition of maladjustments in the regional development processes, in other words transregional development disparities, the social justice and economic progress in the regions, improvement of social standard of living should be provided. The financial planning and forecasts on the regions are of great importance in realization of strategical approach to the financial and investment supply of the regional social and economic development. In Azerbaijan the process of financial planning on the regions is multiple-stage process. On the basis of these standards the salaries expenses in the regions, the electric and telecommunication expenses are determined, and the tax process of the regions is defined in the process of state budget implementation [14]. Against the global economic appeals and in the context of transformation of the global economic processes today the necessity of searching of new and more effective mechanisms of social and economic development management appeared in Azerbaijan [22]. In this context the elimination of differences of the regional social and economic development levels is considered to be one of the priority directions of regional development, and as a result the model of regional financial and investment supply should be developed and implemented. It is known that in the terms of market relations the financial supply is paid by the investments funded by this or another resource [1]. From this point of view the maximum rational ways of strategic approaches of financial and investment supply of the regional social and economic development in Azerbaijan in the short and long terms have to be found. The role of finance and credit organizations in the regional enterprise and business development should be enhanced, the adequate development model of the regional enterprise should be built and in general the financial and investment model of the regional social and economic development should be developed.

\section{Conclusion}

What do we have in conclusion of the issues reviewed in the article? What is barring and missing the financial and investment supply of the social and economic development in the regions of Azerbaijan? It would be expediently to determine the adequate approach to these questions and directions of practical activity. First of all, we should note that the available mechanisms of the financial and investment supply of the regional social and economic development are known: they consist of privileged credits, investments directed to the regional enterprise development, main capital investment, resources, equipment and etc. allocated via leasing. But in each established state program it was prescribed to use the non-budgetary foundation, foreign investment, foreign enterprises resource, financial resources of international organizations and foreign states as funding resource alongside with the state support and state resources for strengthening the regional financial and investment supply. Unfortunately, in connection with this the real measures are on very low level. It must be acknowledged that the active attracting of the foreign investments into Azerbaijan regions, organization of foreign investors' joint activity is still inadequate and many measures have to be taken in this field. The government put a lot of efforts to enterprise development and financial investment supply of the social and economic development in the regions, but the most (80-85\%) enterprises and private firms operating in the regions consist of small enterprises. Generally, on the assumption of modern reality of the social and economic development in the regions it is possible to achieve the following results:

- The social and economic development of the regions in Azerbaijan and the revision and modeling of the financial and investment supply of the development program connected with this is important;

- In the regions of the country there is no finance and credit organizations, finance and investment funds, finance and industry group operating with independent balance and activity program. Generally, such kind of finance and credit organizations were centered in capital city - Baku; - After the devaluation of the local currency-manat the activity of non-bank finance and credit organizations in the regions decreased and this situation made the financial and investment supply in the regions more complex; 
- The enterprises and private farms in the regions have no practical experience in state support mechanisms and privileged credits, and also in searching and attraction of financial and investment resources alternative to subsidies, this means that in this field the measures on raise interest of regional subjects to the educational measures and active participation in the international financial and investment cooperation should be purposefully organized in a complex and system manner;

- With the aim of strengthening the financial and investment supply of the social and economic development in the regions the financial and investment organizations and companies creation should be stimulated and arranged in such formats as 'Regional development funds', 'Regional finance and investment funds', 'Regional investment development banks', 'Regional financial and industrial groups', 'Regional agroindustrial companies' and etc., and the companies, banks, investment funds which possess global experience in the similar spheres should be attracted in this processes. To organize these measurements the international tenders should be held, the concrete financial and investment supply projects should be prepared, the foreign financial and investment companies should be attracted purposefully. Alongside with the local resources and domestic investments, the mechanism of intensive bringing of the foreign investments to the regions of the country should be implemented and etc. We think that the ideas about the regional social and economic development problems and its finance and investment supply, the approaches to the issues, specific characteristics, modeling of solution of finance and investment supply of the regional social and economic development on the country level can attract the attention of global economists, researchers and experts, the state authorities responsible for this sphere. From the other hand Azerbaijan differs with dynamic economic development in positive meaning. Because of this the development of the social and economic development programs and the materials, analysis and judgment on their finance and investment supply modeling keep their chance to become a contribution to the global economics.

\section{References:}

[1] Ahmedzadeh A.H., Modeling the impact of investment on economic development //Azerbaijan National Academy of Sciences, Institute of Economics, Scientific works, 2010, №2.- P. 66-71.
[2] Atashov B.Kh., Financial market. Publishing house "Cooperation", 2016, Baku, 456 p.

[3] Aliev Sh.T., Foreign economic policy of Azerbaijan, 2015, Sumgait: Publishing house of Sumgait State University, 185 p.

[4] Allahverdiev N.B., Gafarov K.S., Ahmedov A.A., State regulation of the national economy, 2012, Baku: «Economical University» Publishing House, 508 p.

[5] Alfred Marshall., (1890-1891). Principles of Economics.

[6] Azerbaijan in figures, State Statistical Committee of the Republic of Azerbaijan, Baku, 2017, $286 \mathrm{p}$.

[7] Arias Maria A., Wen Yi, 2015, Trepped: Few developing countries can climb the economic ladder or stay there // The Regional Economist. http://www.stlouisfed.org.

[8] Ascani Andrea, Crescenzi Riccardo, Lammarino Simona, 2012, Regional Economic Development: a Review, 27 p.

[9] Bagirov N.A., Ways to improve the implementation and management of the socioeconomic development program of the region (2004-2008) Xazar University, Journal "CaspianNews” №174, Baku, 2014, P. 28-29.

[10] Bas van Leeuwen, Jieli van Leeuwen-Li, Peter Foldvari, (2017). Human capital in republican and New China: regional and long-term trends. // Economic History of Developing Regions. Volume 32, - Issue 1. P.1-36. http://www.tandfonline.com.

[11] Brown Ross, Cluster dynamics in theory and practice with application to Scotland // Regional and industrial Policy Research Paper, 2000, №38. http://www.urenio.org.

[12] Chaplyuk V.Z., Prospects for the Development of the Financial and Credit System of Russia // Russian Entrepreneurship, 2006, № 4 (76), P. 16-20.

[13] Caribbean region: review of economic growth and development, 2008, United States International Trade Commission, Washington, 234 p. http://www.ustic.gov.

[14] Capello Roberta, Location, regional growth and location development theories, AESTIMUM 58, Giungno , 2011, P.125.http://www.fupress.net.

[15] Florida Richard, Entrepreneurship, creativity and regional development. Carnegie Mellon University, 2002, 30 p., http://www.creativeclass.com

[16] Gazizulina I.A., The financial and investment potential for the development of the region. (On 
the example of the Novosibirsk region), 2011 Moscow, $153 \mathrm{p}$.

[17] Gadzhieva N.G., (2015). Implementation of national economic interests and regional development in Azerbaijan. Nakhchivan branch of the National Academy of Sciences of Azerbaijan, Naxchivan,54 p.

[18] Gren Jörgen, (2003). Reaching the Peripheral Regional Growth Centres // European Journal of Spatial Development, Jan 2003-no3. http://www.nordregio.se.

[19] Gonzalez-Pernia Jose L., Lagazkue-Pena Inaki. Export-oriented entrepreneurship and regional economic growth. Basque Institute of Copmpetitivness. University of Deusto, $16 \mathrm{p}$. http://www.workspace.imperial.ac.uk.

[20] Harshana Kasseeah, (2016). "Investigating the impact of entrepreneurship on economic development: a regional analysis", Journal of Small Business and Enterpise Development, Vol. 23 Issue: 3, pp.896-916. http://www.doi.org/10.1108/JSBED-092015-0130. [21] Hasanli Y.H., (2011). Modeling of interbranch relations in Azerbaijan's economy. Baku, "Science", $205 \mathrm{p}$.

[22] Huseynova Kh.M., (2010). Features of the development of the regions of Azerbaijan // Journal - Intercultural Relations Society, Georgia, (12).-P. 92-97.

[23] Huseynova Kh.M., (2010) Regional development programs: theoretical and practical issues // Monograph. Baku, $223 \mathrm{p}$.

[24] Huseynova Kh.M., (2011). The socioeconomic aspects of regional development in Azerbaijan // Azerbaijan National Academy of Sciences, Institute of Economics, Scientific works, Baku, (1). P. 254-261.

[25] Huanyong $\mathrm{Hu}$, (1985). Population growth in China's eight major regions and program for economic development and economic zones //Geograohical Research. 4(4): P.1-9. http://www.dlyj.ac.

[26] Hyman Glenn, Barona Elizabeth, Espinosa Herlin, Cardona Jorge, (2016). Priority regions for research on dryland cereals and legumes. http://www.f1000research.com.

[27] Korchagina Y.V., (2012). Methods for assessing the sustainable development of regional socio-economic systems. Problems of the modern economy. № 1 (41), Moscow, P. 67-71.

[28] Khakimova Y.A., (2014). Evaluation of the financial mechanism ensuring socioeconomic development of the regions // Science News of Azerbaijan State Economic University, Volume 2, P. 93-103.
[29] Keynes M. John., (1936). General Theory of Employment, Interest and Money.

[30] Lecarte Jacques. European Regional Development Fund (ERDF). EU fact sheets. http://www.europarl.europa.eu.

[31] Luca Di Persio, Oleksandr Honchar, Multitask machine learning for financial forecasting, International Journal of Circuits, Systems and Signal Processing, pp. 444-451, Volume 12, 2018.

[32] Mamedova G.G., (2012). Macroeconomic problems of improving the financial system. Azerbaijan State Economic University.Baku, 32 p. [33] Malganova Irina, Zagladina Helena, (2015). Regional socio-economic development on the basis of scenario forecasting method // Procedia Economics and Finance, 24, P. 371-375. http://www.elsevier.com .

[34] Nuriyev A.H., (2013). The conceptual basics of the economic development and modernization policy in Azerbaijan. Baku, Avrora, $442 \mathrm{p}$.

[35] National accounts of Azerbaijan., (2016). Statistical year book State Statistical Committee of the Republic of Azerbaijan. Baku, 181 p.

[36] Nuur Cali, Laestadius Staffan, (2010). Development in peripheral regions: Case studies in Sweden // European Urban and Regional Studies. http://www.journals.sagepub.com.

[37] Otsuka Akihiro, Yamano Norihiko, (2006). Industrial Agglomeration Effects on Regional Economic Growth: A Case of Japanese Regions. Socio-Economic Research Center, Central Research Institute of Electric Power Industry.-27 p. [38] Perloff M.S., (1957). "Regional Studies at U.S.Universities. "A Survey of Regionally Oriented Research and Graduate Ed, Activities, Washington D.C.

[39] Rzayev P.Q.,(2011). The tax aspects of regulation of investments // Tax Journal of Azerbaijan, №5, $\quad$ P. $69-82$. http://www.vergijurnali.az/az/pages/4/.

[40] Ragimov M.R., (2014). Directions of increasing the rationality of using the investment potential of the region (on the example of the Aran economic region) Baku, $23 \mathrm{p}$.

[41] Ragimov M.R., (2013) Estimation of the level of use of investment potential in the Aran economic region//Azerbaijan National Academy of Sciences, Institute of Economics, Scientific works. Baku, P. 242-247.

[42] Regions of Azerbaijan, (2016). State statistical Committee of the Republic of Azerbaijan, Baku, 820 p.

[43] Rakar Fredrik., Tallberg Pontus, (2014). Deve-loping Regions for Regional Development- 
Towards a new Swedish model. Sweden, 140p. http://www.regionalstudies.org.

[44] Samuelson P.A., Nordhaus W.D. Economics, (2009). McGraw-Hill/Irwin; 19th edition.

[45] Sadygov E.M., (2013). Improving the rationality of investment financing. Azerbaijan State Economic University. Baku, 24 p.

[46] Shirinov Sh.V.,(2012). The problems of regulating the sustainability of the economic development of Azerbaijan. // Bulletin of economic integration № 7, Moscow, P. 164-167.

[47] Smith, Adam., (1909-14; 2001). Wealth of Nations, edited by C. J. Bullock. Vol. X. The Harvard Classics. New York: P.F. Collier \& Son, Bartleby.com.

[48] Stiglitz E. Jozeph, Charlton Andrew., (2005). Fair Trade For all. How trade can promote development. Oxford University Press.

[49] Solow Robert Merton.,(1974). The Economic of Resources and the Resources of Economics.

[50] Statistical yearbook of Azerbaijan, (2016). «State statistical Committee of the Republic of Azerbaijan». Baku, 824 p.

[51] Storper Michael, (2011). Why do regions develop and change? The challenge for geography and economics // Journal of Economic Geography, 11(2): P. 333-346. http://www.academic.oup.com . [52] Tolstolesova L.A., (2010). The raw materials regions and investment strategies // Journal of Russian Entrepreneurship, No. 8 (2)-P.159-163.

[53] Tabellini Guido, (2006). Culture and institutions: economic development in the regions of Europe. IGIER, Bocconi University. -73 p. http://www.dklevine.com.

[54] Venables Anthony J, (2003). Spatial Disparities in developing countries: cities, regions and international trade. http://www.eprints.ise.as.uk.

[55] Xia Li, Optimization of VRP for Single Distribution Center Based on Improved Saving Method, International Journal of Circuits, Systems and Signal Processing, pp. 213-221, Volume 13, 2019.

[56] Xiaohua Duan, Systematic Risk Measurement Based on CoVaR Model, International Journal of Circuits, Systems and Signal Processing, pp. 243250, Volume 13, 2019.

\section{Creative Commons Attribution License 4.0 (Attribution 4.0 International, CC BY 4.0)}

This article is published under the terms of the Creative Commons Attribution License 4.0 https://creativecommons.org/licenses/by/4.0/deed.en_US 